\title{
Path Analysis on the Effect of Healthy Behavior and other Determinants on Infant Mortality: Evidence from Karanganyar District, Central Java
}

\author{
Endang Palupi'), Harsono Salimo²), Bhisma Murti'1) \\ ${ }^{1)}$ Masters Program in Public Health, Universitas Sebelas Maret \\ 2)Departement of Pediatrics, Dr. Moewardi Hospital, Surakarta
}

\begin{abstract}
Background: One indicator of a country's progress is the infant mortality rate. Infant mortality is affected by many factors, both exogenous and endogenous. This study aimed to determine the factors causing significant infant mortality to reduce infant mortality in Karanganyar Regency.
\end{abstract}

Subjects and Method: This study was an observational study with a cross-sectional design. This study was conducted in Karanganyar, Central Java, from February to May 2020. A sample was 200 infants aged 1-11 months were selected by fixed disease sampling. The variables observed for the effect were infant mortality, clean and healthy life behavior, exclusive breastfeeding, parental income, maternal education, infant nutritional intake, immunization status, birth weight of infants, illness history of infants, health services, and house sanitation. The data were collected by questionnaire and analyzed using path analysis with Stata 13.

Results: The risk of infant mortality increased by the cleanliness of the home environment $(b=3.84 ; 95 \% C I=1.76$ to $5.92 ; p<0.001)$, infant nutrition intake $(\mathrm{b}=4.07 ; 95 \mathrm{CI}=2.25$ to 5.89 ; $\mathrm{p}<0.001)$, illness history of infants $(b=3.03$;
95\% $\mathrm{CI}=1.34$ to $4.72 ; \mathrm{p}<0.001)$. The risk of infant mortality decreased by clean and healthy life behavior $(b=-5.34 ; 95 \% C I=-7.75$ to $-2.94 ; p$ $<0.001)$. Infant mortality was affected indirectly by exclusive breastfeeding, parental income, maternal education, birth weight of infants, immunization status, and health care facilities.

Conclusion: Infant mortality is directly affected by the cleanliness of the home environment, clean and healthy life behavior, nutritional intake of infants, and illness history of infants. Infant mortality is indirectly affected by exclusive breastfeeding, parental income, maternal education, birth weight of infants, immunization status, and health care facilities.

Keywords: Healthy behavior, determinant infant mortality, path analysis

\section{Correspondence:}

Endang Palupi. Masters Program in Public Health, Universitas Sebelas Maret. Jl. Ir. Sutami 36A, Surakarta 57126, Central Java. Email: epalupi11@gmail.com. Mobile: +6281331872723 .

\section{Cite this as:}

Palupi E, Salimo H, Murti B (2020). Path Analysis on the Effect of Healthy Behavior and other Determinants on Infant Mortality: Evidence from Karanganyar District, Central Java. J Matern Child Health. 05(05): 467481. https://doi.org/10.26911/thejmch.2020.05.05.02.

cc) (7) (-) Journal of Maternal and Child Health is licensed under a Creative Commons Attribution-NonCommercial-ShareAlike 4.o International License.

\section{BACKGROUND}

One indicator of health status in a country is the infant mortality rate. Infant mortality is the death of a child before reaching one year of life. The important period of a child's future life is at an early age, namely at the age of infants. Good quality of life for infants needs to be considered from various aspects such as infant health, clean environment, and healthy habits for mothers and families. Therefore, the risk of illness and death does not increase. Globally, there were 4.6 million deaths occurred each year during infancy, $99 \%$ of the cases occurred 
in developing countries (Lamichhane et al., 2017).

Based on the data of WHO (2019), 4.1 million deaths $(75 \%$ of all children under five deaths) occurred in the first year of life. Globally, the infant mortality rate decreased from an estimated rate of 65 deaths per 1,000 live births in 1990 to 29 deaths per 1,000 live births in 2017. The World Bank (2017) added that the infant mortality rate decreased by $2.8 \%$ globally (28.9 per 1000 live births) from 2014 to 2018. Based on the supporting data on the infant mortality rate in Indonesia, there was a decrease of 25\% from 2012 to 2017 (24 per 1000 live births). It showed that 1 of 42 infants died before one year of age. The trend of infant mortality would be slower if the preventive efforts did not carry out. It was estimated that around half of the 69 million child deaths would occur between 2016 and 2030. In addition, infant mortality would occur before one year of age due to various causes (UN IGME, 2015).

From the health aspect, there were three causes of infant mortality, such as acute respiratory infection (ARI), perinatal complication, and diarrhea. At least, $75 \%$ of these three causes contributed to the incidence of infant mortality (Ministry of National Development Planning, 2015). Child health is a crucial general indicator of health problems besides infant mortality. Efforts to know broadly about the things related to this incident and the study that could be linked to efforts to improve the quality of life of infants by improving nutrition, quality of feeding and/or breastfeeding, and improving environmental sanitation need to be conducted (Ware et al., 2016).

Based on the result of the Indonesian Nursing Diagnosis Standard (2017) in Central Java, the IMR was 8.9 per 1,000 live births. Karanganyar Regency contri- buted 12.7 per 1 ,000 live births. It was ranked 5 from the top in Central Java Province. In developing human resources, the Karanganyar Regency government expected to increase health status by targeting IMR <8.2 per 1,000 KH in 2023 (Karanganyar Regency Health Office, 2020)

In Karanganyar Regency, a study on infant mortality observed from the perspective of the Clean and Healthy Life Behavior pattern, economic status, level of health services, and the contextual effect of the village where the baby lived that was linked simultaneously to determine the effect on infant mortality has never been carried out. Therefore, the authors were interested in conducting this study.

\section{SUBJECTS AND METHOD}

\section{Study Design}

This was an analytical observational study with a cross-sectional approach using a path analysis model.

\section{Population and Sample}

The population of this study was infants aged 6 to 11 months in Karanganyar, Central Java. A sample was 200 infants was selected by fixed disease sampling

\section{Study Variables}

The variables observed in this study were infant mortality, clean and healthy life behavior, exclusive breastfeeding, parental income, maternal education, birth weight, immunization status, illness history of infants, nutritional intake, birth weight of infants, health care facilities, and environmental hygiene.

\section{Operational Definition of Variables} Infant mortality was a baby who died at the age of fewer than 11 months. The measuring instrument was questionnaire. The data scale was dichotomous data with code $\mathrm{O}=$ live babies and code $1=$ dead babies.

Clean and Healthy Life Behavior was a group of individual behaviors based on 
awareness, as a result of independent learning for their own health to create public health. It was measured by 10 indicators of clean and healthy life behaviors. The measuring instrument was questionnaires. The data scale was continous data. The data was converted into dichotomous data to facilitate the analysis. Code $\mathrm{O}=$ did not do clean and healthy life behavior $(<8.58)$; and $1=$ did clean and healthy life behavior $(\geq 8.58)$.

Exclusive breastfeeding was giving breast milk to babies at the age of o-6 months without providing additional food. The measuring instrument was questionnaire. The data scale was continous data. The data was converted into dichotomous data to facilitate the analysis. Code $\mathrm{O}=$ nonexclusive breastfeeding $(<3.47)$; and $1=$ exclusive breastfeeding $(\geq 3 \cdot 47)$.

Parental income was the average family income in the last six months and when the baby died. The measuring instrument was questionnaires. The data scale was continous data. The data was converted into dichotomous data to facilitate the analysis. Code $\mathrm{O}=<$ minimum wage of Karanganyar Regency ( $<$ Rp. 1,833,000); and $1=\geq$ minimum wage of Karanganyar Regency ( $\geq$ Rp. 1,833,000).

Maternal education was the last education that a mother took. The measuring instrument was questionnaires. The data scale was categorical data. The data was converted into dichotomous data to facilitate the analysis. Code $\mathrm{O}=$ low education (<Senior High School); and 1=high education ( $\geq$ Senior High School).

The nutritional intake of infants was the intake that babies received. It could be breastmilk only for 6 months or additional food at the right age. The measuring instrument was questionnaire. The data scale was continous data. The data was converted into dichotomous data to facilitate the analysis. Code $\mathrm{O}=$ good nutritional intake (<1.99); and $1=$ malnutrition/ insufficient intake ( $\geq 1.99$ ).

Immunization status was the immunization baby received. The measuring instruments were questionnaires and the Card towards Health. The data scale was categorical data. The data was converted into dichotomous data to facilitate the analysis. Code $\mathrm{O}=$ incomplete immunization; and $1=$ complete immunization.

Illness history of infants was the illness infants had during their lifetime. The measuring instrument was questionnaires. The data scale was continous data. The data was converted into dichotomous data to facilitate the analysis. Code $\mathrm{O}=$ rarely sick $(<1.97)$; and $1=$ often sick $(\geq 1.97)$.

Birth weight of infants was the weight of the baby at birth. The measuring instruments were questionnaires and the Card towards Health. The data scale was categorical data. The data was converted into dichotomous data to facilitate the analysis. Code $\mathrm{O}=$ normal birth weight $(<2500 \mathrm{~g})$; and $1=$ abnormal birth weight ( $\geq 2500 \mathrm{~g}$ ).

House sanitation was a condition of environmental hygiene seen from water sanitation, air sanitation, and landfills. The measuring instrument was questionnaires. The data scale was continous data. The data was converted into dichotomous data to facilitate the analysis. Code $\mathrm{O}=$ good environmental hygiene $(<9.71)$; and $1=$ poor environmental hygiene $(\geq 9 \cdot 71)$.

Health facility was a place of health care that was intended by mothers and babies to handle their health. The measuring instrument was questionnaires. The data scale was categorical data. The data was converted into dichotomous data to facilitate the analysis. Code $\mathrm{o}=$ primary health care and code $1=$ secondary health care. 
Palupi et al./ Healthy Behavior and other Determinants on Infant Mortality

\section{Study Instruments}

The instrument of this study was questionnaire. The questionnaire in this study consisted of several parts. The instrument of this study used a questionnaire. The questionnaire in this study was in the form of open and closed questionnaires. The author provided the answers in the questionnaire so that the respondent chose the answer according to the condition and filled in according to reality.

\section{Data Analysis}

Univariate analysis aimed to describe each dependent variable and the independent variable. The data were grouped according to the type of data. The contextual data were presented with mean, standard deviation, minimum, and maximum values. The dichotomy data were attached to the frequency distribution table.

Bivariate analysis aimed to determine the relationship between the independent variable and the dependent variable using the Chi-square test.

Multivariate analysis aimed to explain the relationship of the effect among variables. Multivariate analysis was carried out by path analysis.

\section{Research Ethics}

This study paid attention to the basic principles of research ethics and has applied for ethical clearance from the Health Research Ethics Commission of Dr. Moewardi Hos- pital with the Ethical Clearance Number: 566/II/HREC/2020 on March 10, 2020.

\section{RESULTS}

1. The Characteristics of the Sample

The characteristic of the sample is in Table 1 and 2. Table 1 describes the sample measurements on 200 mothers and infants as the subjects who met the inclusion criteria. The variable of infant age had a mean= 11.23 months and $\mathrm{SD}=6.09$ with a minimum age of 1 month and a maximum age of 24 months. The variable of infant's birth weight had a mean $=2818$ grams and $\mathrm{SD}=$ 681 with a minimum value of 300 grams and a maximum value of 4300 grams. The variable of maternal age had a mean $=\mathbf{2 4 . 8 6}$ years and $\mathrm{SD}=3.77$ with a minimum age $=16$ years and a maximum age $=37$ years. The variable of family income had a mean=Rp. $2,300,375$ and $\mathrm{SD}=\operatorname{Rp} 1,318,146$. The variable of the distance between houses and health care facilities had a mean $=4.53 \mathrm{~km}$ and $\mathrm{SD}=5.60$ with a minimum distance $=$ $300 \mathrm{~km}$ and a maximum distance $=4,300$ $\mathrm{km}$.

Table 2 shows that most of the study subjects were $\geq 25$ years old. 116 study subjects had a high school education (58\%). More than half $(74.5 \%)$ of families had income $>$ minimum wage. The sex of the infants was mostly female. There were 101 infants who had LBW>2500 (71.5\%). There were 50 infants who died (25\%).

Table 1. The characteristics of the sample (continuous data)

\begin{tabular}{lccccc}
\hline Characteristic & n & Mean & SD & Min. & Max. \\
\hline Infant age (month) & 200 & 11.23 & 6.09 & 1 & 24 \\
Birth weight of infants (gram) & 200 & 2,818 & 681 & 300 & 4,300 \\
Maternal age (year) & 200 & 24.86 & 3.77 & 16 & 37 \\
Family income (rupiah) & 200 & $2,300,375$ & $1,318,146$ & 350,000 & 9, ooo,ooo \\
The distance between the house & 200 & 4.53 & 5.60 & 300 & 4,300 \\
and the health service facility (km) & & & & & \\
\hline
\end{tabular}


Palupi et al./ Healthy Behavior and other Determinants on Infant Mortality

Table 2. The characteristics of the sample (dichotomous data)

\begin{tabular}{lcc}
\hline Characteristic & $\mathbf{n}$ & $\mathbf{\%}$ \\
\hline Maternal Age & & \\
< 25 years & 97 & 48.5 \\
$\geq 25$ years & 103 & 51.5 \\
Maternal Education & 2 & 1 \\
Elementary School & 40 & 20 \\
Junior High School & 116 & 58 \\
Senior High School & 17 & 8.5 \\
Diploma 1/ Diploma 2/ Diploma3 & 25 & 12.5 \\
Bachelor/Master/Doctoral degree & & \\
Birth weight of infants & 57 & 28.5 \\
< 2500 gram & 143 & 71.5 \\
$\geq 2500$ gram & & \\
Infant Mortality & 150 & 75 \\
Alive & 50 & 15 \\
Dead & & \\
Sex & 101 & 50.5 \\
Female & 99 & 49.5 \\
Male & & \\
Family income & 51 & 25.5 \\
< Rp 1,833,000 & 149 & 74.5 \\
\hline Rp 1,833,000 & & \\
\hline
\end{tabular}

\section{Univariate Analysis}

The univariate analysis is described in Tables 3 and 4. Table 3 describes the values of the characteristic of the study variables which measured 200 samples, mean, standard deviation, minimum value, and maximum value. The variable of clean and healthy life behavior had a mean $=8.58$, $\mathrm{SD}=1.49$, $\min =5$ and $\max =10$. The exclusive breastfeeding had a mean $=3.47, \mathrm{SD}=$ 1.40, $\min =0$ and $\max =5$. The nutritional intake of infants had a mean $=1.99, \mathrm{SD}=1.15$, $\min =0$ and $\max =3$. The illness history of infants had a mean=1.97, $\mathrm{SD}=1.14, \min =0$ and $\max =3$. The cleanliness of the home environment had a mean=9.71, $\mathrm{SD}=1.80$, $\min =4$ and $\max =11$.

Table 4 shows that $66 \%$ of families who had infants in Karanganyar Regency implemented clean and healthy life behavior. Exclusive breastfeeding in infants was fewer than half (58\%) and undernourished infants were $29.5 \%$. The infants who had complete immunization status were $71 \%$ and the infants who were rarely sick were $64 \%$. Most of the infants' birth weight was $>2500$ grams (71.5\%). Most of the infants accessed primary health care facilities (68\%). Good environmental hygiene was $67.5 \%$.

Table 3. Univariate Analysis (continuous data)

\begin{tabular}{lccccc}
\hline Characteristic & n & Mean & SD & Min. & Max. \\
\hline Clean and Healthy Life Behavior & 200 & 8.58 & 1.49 & 5 & 10 \\
Exclusive breastfeeding & 200 & 3.47 & 1.40 & 0 & 5 \\
Nutritional intake of infants & 200 & 1.99 & 1.15 & 0 & 3 \\
Illness history of infants & 200 & 1.97 & 1.14 & 0 & 3 \\
Cleanliness of home environment & 200 & 9.71 & 1.80 & 4 & 11 \\
\hline
\end{tabular}


Palupi et al./ Healthy Behavior and other Determinants on Infant Mortality

Table 4. Univariate analysis (dichotomous data)

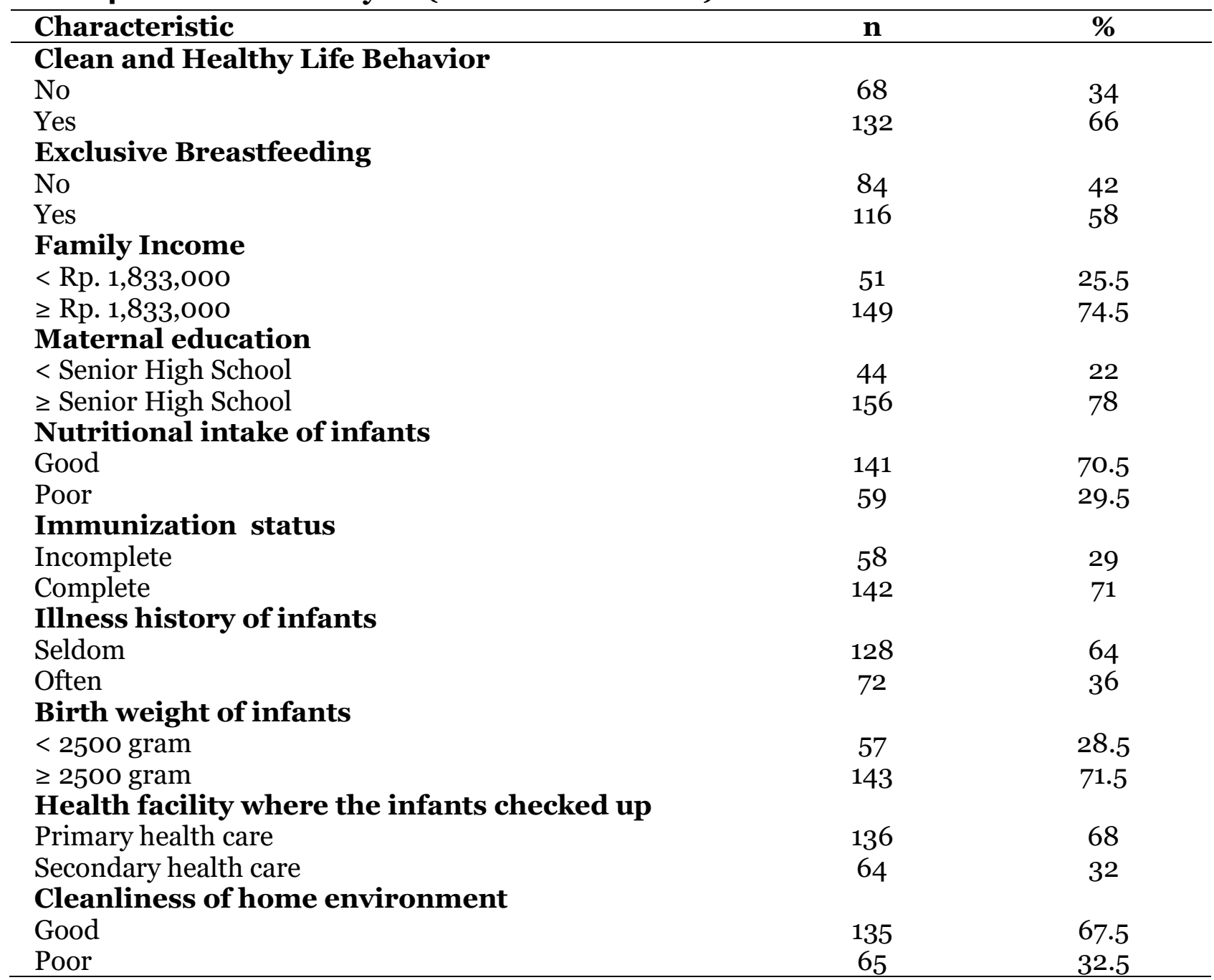

\section{Bivariate analysis}

This study used the chi-square test to analyze the study. It explained the relationship between the dependent variable (infant mortality) and one independent variable (clean and healthy life behavior, exclusive breastfeeding, parental income, maternal education, infant nutritional intake, immunization status, illness history of infants, LBW, health care facilities, and cleanliness of the home environment). The results of the bivariate analysis can be seen in Table 5 .

Table 5 shows the results of the Chisquare test of the relationship between infant mortality and clean and healthy life behavior. It had a risk of infant mortality by o.05 times compared to the infants whose families did not have clean and healthy life behavior $(\mathrm{OR}=0.05 ; 95 \% \mathrm{CI}=0.02$ to 0.13 ; $\mathrm{p}<0.001)$. Infants who were exclusively breastfed had 0.04 times of experiencing death compared to the infants who were not exclusively breastfed (OR $=0.04 ; 95 \%$ $\mathrm{CI}=0.01$ to $0.13 ; \mathrm{p}<0.001)$. The infants whose families had high income $(\geq \mathrm{Rp}$ $1,833,000$ ) had 0.02 times the risk of experiencing death compared to babies whose families had low income $(<\mathrm{Rp}$ $1,833,000)(\mathrm{OR}=0.02 ; 95 \% \mathrm{CI}=0.001$ to $0.07 ; \mathrm{p}<0.001)$. 
Palupi et al./ Healthy Behavior and other Determinants on Infant Mortality

Table 5. The chi-square test of factors affecting infant mortality

\begin{tabular}{|c|c|c|c|c|c|c|c|c|}
\hline \multirow{3}{*}{ Independent Variable } & \multicolumn{4}{|c|}{ Infant mortality } & \multirow{3}{*}{$\mathbf{O R}$} & \multirow{2}{*}{\multicolumn{2}{|c|}{ 95\% CI }} & \multirow{3}{*}{ p } \\
\hline & \multicolumn{2}{|c|}{ Alive } & \multicolumn{2}{|c|}{ Died } & & & & \\
\hline & $\mathbf{N}$ & $\%$ & $\mathbf{N}$ & $\%$ & & $\begin{array}{l}\text { Lower } \\
\text { limit }\end{array}$ & $\begin{array}{l}\text { Upper } \\
\text { limit }\end{array}$ & \\
\hline \multicolumn{9}{|c|}{ Clean and Healthy Life Behavior } \\
\hline No & 28 & 41.18 & 40 & 31.1 & \multirow{3}{*}{0.05} & \multirow{3}{*}{0.02} & \multirow{2}{*}{0.13} & \multirow{3}{*}{$<0.001$} \\
\hline Yes & 122 & 92.42 & 10 & 7.58 & & & & \\
\hline \multicolumn{6}{|l|}{ Exclusive breastfeeding } & & & \\
\hline No & 40 & 47.62 & 44 & 52.38 & \multirow{2}{*}{0.04} & \multirow{2}{*}{0.016} & \multirow{2}{*}{0.13} & \multirow{2}{*}{$<0.001$} \\
\hline Yes & 110 & 94.83 & 6 & 5.17 & & & & \\
\hline \multicolumn{9}{|l|}{ Family income } \\
\hline$<\operatorname{minim} \iota$ & 13 & 25.49 & 38 & 74.51 & \multirow{2}{*}{0.02} & \multirow{2}{*}{0.01} & \multirow{2}{*}{0.07} & \multirow{2}{*}{$<0.001$} \\
\hline $\begin{array}{l}\geq \text { minimum wage } \\
\text { Maternal education }\end{array}$ & 137 & 91.95 & 12 & 8.05 & & & & \\
\hline$<$ Senior High School & 12 & 27.27 & 32 & 72.73 & \multirow{3}{*}{0.04} & \multirow{3}{*}{0.01} & \multirow{3}{*}{0.11} & \multirow{3}{*}{$<0.001$} \\
\hline$\geq$ Senior High School & 138 & 88.46 & 18 & 11.54 & & & & \\
\hline \multicolumn{5}{|c|}{ Nutritional intake of infants } & & & & \\
\hline Good & 132 & 93.62 & 9 & 6.38 & \multirow{3}{*}{$33 \cdot 40$} & \multirow{3}{*}{13.00} & 8020 & $<0,001$ \\
\hline Poor & 18 & 30.51 & 41 & 69.49 & & & 89.29 & $<0.001$ \\
\hline Immunization status & & & & & & & & \\
\hline Incomplete & 15 & 25.86 & 43 & 76.14 & 0.01 & 0.006 & 0.05 & $<0,001$ \\
\hline Complete & 135 & 95.07 & 7 & 4.93 & 0.01 & 0.000 & 0.05 & $<0.001$ \\
\hline Illness history of infan & & & & & & & & \\
\hline Seldom & 115 & 89.84 & 13 & 10.16 & 9.35 & 4.24 & 21.1 & $<0.001$ \\
\hline Often & 35 & 48.61 & 37 & 51.39 & 9.35 & 4.24 & 21.1 & $<0.001$ \\
\hline Birth weight of infants & & & & & & & & \\
\hline$<2500$ gram & 25 & 43.86 & 32 & 56.14 & 0.11 & 0.51 & 0.24 & $<0.001$ \\
\hline$\geq 2500$ gram & 125 & 87.41 & 18 & 12.59 & & $0.5^{1}$ & 0.24 & \\
\hline Cleanliness of home e & ironı & ent & & & & & & \\
\hline Good & 121 & 89.63 & 14 & 10.37 & 10.72 & 4.84 & 24.19 & $<0.001$ \\
\hline Poor & 29 & 44.62 & 36 & $55 \cdot 38$ & $10 . / 2$ & 4.04 & 24.19 & -0.001 \\
\hline Hea & & & & & & & & \\
\hline Primary health care & 117 & 86.03 & 19 & 13.97 & 5.78 & 2.74 & 12.24 & $<0.001$ \\
\hline Secondary health care & 33 & 51.56 & 31 & 48.44 & & & & \\
\hline
\end{tabular}

The infants with highly educated mothers had 0.04 times the risk of experiencing death compared to infants with mothers with low education ( $\mathrm{OR}=0.04 ; 95 \% \mathrm{CI}=$ 0.01 to $0.11 ; \mathrm{p}<0.001)$. The infants who had a poor nutritional intake were 33.4 times more likely to die than the infants who had a good nutritional intake $(\mathrm{OR}=33.4 ; 95 \%$ $\mathrm{CI}=13$ to $89.29 ; \mathrm{p}<0.001)$. The ifants with complete immunization status had 0.18 times the risk of experiencing death than the infants with incomplete immunization status $(\mathrm{OR}=0.18 ; 95 \% \mathrm{CI}=0.006$ to 0.51 ; $\mathrm{p}<0.001)$. The infants who were often sick were 9.35 times more likely to die than the infants who were rarely sick $(\mathrm{OR}=9.35$; $95 \% \mathrm{CI}=4.24$ to $21.1 ; \mathrm{p}<0.001)$. The infants who had 2500 grams at birth had 0.11 times the risk of experiencing death than the infants who had less than 2500 grams at birth $(\mathrm{OR}=0.11 ; 95 \% \mathrm{CI}=0.51$ to $0.24 ; \mathrm{p}$ $<0.001)$. The infants with poor environmental hygiene had 10.72 times the risk of experiencing death compared to the infants with good environmental hygiene (OR= 10.72; 95\%CI $=4.84$ to 24.19; $\mathrm{p}<0.001)$. The infants who received secondary health care had 5.78 times the risk of experiencing 
Palupi et al./ Healthy Behavior and other Determinants on Infant Mortality

death compared to the infants who received primary health care $(\mathrm{OR}=5.78 ; 95 \% \mathrm{CI}=2.74$ to $12.24 ; \mathrm{p}<0.001)$.

\section{Multivariate Analysis}

Multivariate analysis explained the relationship between infant mortality, clean and healthy life behavior, exclusive breastfeeding, parental income, maternal education, infant nutritional intake, immunization status, illness history of infants, LBW, health care facilities, and the cleanliness of the home environment.

Table 6. Path analysis of infant mortality

\begin{tabular}{|c|c|c|c|c|c|c|}
\hline \multirow[b]{2}{*}{$\begin{array}{l}\text { Dependent } \\
\text { Variable }\end{array}$} & & \multirow[b]{2}{*}{ Independent Variable } & \multirow[b]{2}{*}{$\mathbf{b}$} & \multicolumn{2}{|c|}{$95 \% \mathrm{CI}$} & \multirow[b]{2}{*}{$\mathbf{p}$} \\
\hline & & & & $\begin{array}{c}\text { Lower } \\
\text { limit }\end{array}$ & $\begin{array}{l}\text { Upper } \\
\text { limit }\end{array}$ & \\
\hline \multicolumn{7}{|l|}{ Direct Effect } \\
\hline \multirow[t]{4}{*}{ Infant mortality } & $\leftarrow$ & Clean and healthy life behavior & $-5 \cdot 35$ & -7.75 & -2.94 & $<0.001$ \\
\hline & $\leftarrow$ & Nutritional intake fo infants & 4.07 & 2.25 & 5.98 & $<0.001$ \\
\hline & $\leftarrow$ & Illness history of infants & 3.03 & 1.34 & 4.72 & $<0.001$ \\
\hline & $\leftarrow$ & Environmental hygiene & 3.84 & 1.76 & 5.92 & $<0.001$ \\
\hline \multicolumn{7}{|l|}{ Indirect Effect } \\
\hline Illness history of & $\leftarrow$ & Health facility & 1.17 & 0.49 & 1.85 & 0.001 \\
\hline infants & $\leftarrow$ & Immunization status & -1.77 & -2.46 & -1.07 & $<0.001$ \\
\hline Nutritional & $\leftarrow$ & Birth weight & -1.09 & -1.82 & -0.36 & 0.003 \\
\hline \multirow[t]{2}{*}{ intake of infants } & $\leftarrow$ & Exclusive breastfeeding & -1.09 & -1.80 & -0.38 & 0.002 \\
\hline & $\leftarrow$ & Maternal education & -1.40 & -2.19 & -0.62 & $<0.001$ \\
\hline $\begin{array}{l}\text { Exclusive } \\
\text { breastfeeding }\end{array}$ & $\leftarrow$ & Parental income & 1.25 & 0.59 & 1.92 & $<0.001$ \\
\hline $\begin{array}{l}\text { N observation= } \\
\text { Log likelihood= }\end{array}$ & 1.91 & & & & & \\
\hline
\end{tabular}

Table 6 shows that there was an effect on the relationship among variables. It could be directly or indirectly affected infant mortality.

Infant mortality was directly affected by clean and healthy life behavior $(b=-5.35$; 95\% CI $=-7.75$ to $-2.94 ; \mathrm{p}<0.001$ ), nutritional intake $(\mathrm{OR}=4.07 ; 95 \% \mathrm{CI}=2.25$ to 5.89 ; $\mathrm{p}<0.001)$, illness history of infants $(\mathrm{b}=$ 3.03; 95\% CI= 1.34 to 4.72 ; $\mathrm{p}<0.001$ ), environmental hygiene $(\mathrm{b}=3.84 ; 95 \% \mathrm{CI}=1.76$ to 5.92; $\mathrm{p}<0.001)$. Infant mortality was indirectly affected by exclusive breastfeeding $(\mathrm{b}=-1.09 ; 95 \% \mathrm{CI}=-1.80$ to $-0.038 ; \mathrm{p}=$ 0.002), family income $(b=-1.25 ; 95 \% \mathrm{CI}=$ 0.59 to $1.92 ; \mathrm{p}<0.001)$, maternal education $(b=-1.40 ; 95 \% C I=-2.19$ to $-0.62 ; p<0.001)$, immunization status $(\mathrm{b}=-1.77 ; 95 \% \mathrm{CI}=-$ 2.46 to $-0.07 ; \mathrm{p}<0.001)$, LBW $(\mathrm{b}=-1.09$; 95\% $\mathrm{CI}=-1.82$ to $-0.36 ; \mathrm{p}=0.003)$, health care facilities $(\mathrm{OR}=1.17 ; 95 \% \mathrm{CI}=0.49$ to $1.85 ; \mathrm{p}=0.001)$.

\section{DISCUSSION}

1. The effect of clean and healthy life behavior on infants mortality

The results of this study showed that there was a direct effect of clean and healthy life behavior on infant mortality. The result was statistically significant $(b=-5.34 ; 95 \% \mathrm{CI}=-$ 7.75 to $-2.94 ; \mathrm{p}<0.001)$. The infants whose families implemented clean and healthy life habits had 5.34 units lower loggodd of experiencing death than the infants whose families did not implement clean and healthy life behavior.

This is in line with a study by Vijay and Patel (2020) that infant mortality was caused by the clean and healthy life behavior of the mother towards the baby. The risk of infant mortality in Bangladesh was 1.5 times higher for mothers who did not give birth in health care facilities, was 
not handled by health workers, and did not monitor their baby's development.

The clean and healthy life behavior program included several points that were likely to cause infant mortality, as stated by Kawuki et al., (2020) in Nangabo South Africa, babies who lived in households that had toilets, used clean water and good water sanitation would reduce the sick each month. In addition, $34 \%$ of babies with poor handwashing habits experienced sick every month. In infants aged 1-6 months, the habit of mothers washing their hands before breastfeeding was a great concern because it could reduce diarrhea in babies. Based on a study conducted in Cordoba, $39 \%$ of babies who lived with family members who smoke had respiratory problems and $14.9 \%$ of babies had acute respiratory problems that lead to death (Teijeiro et al., 2020).

\section{The effect of exclusive breastfeed- ing on infants mortality}

The result of this study showed that there was an indirect effect between exclusive breastfeeding and infant mortality. The result was statistically significant $(b=-1.09$; 95\% $\mathrm{CI}=-1.80$ to $-0.38 ; \mathrm{p}=0.002)$. The infants who were exclusively breastfed had an illness history less frequently and had good growth and development. The infants who were exclusively breastfed had $\mathbf{1 . 0 9}$ units lower loggodd of experiencing death than the infants who were not exclusively breastfed.

Based on a study conducted by Dalili et al., (2019), the duration of breastfeeding in infants greatly affected the quality of the baby's immune system. The infants who had breastfeeding duration of fewer than 4 months were categorized as heterogeneity. Based on the result of the study, the significant illnesses $(p<0.001)$ were respiratory disease, obesity, stunting, and sudden infant death syndrome (SIDS).
The infants who were sick needed more adequate breast milk intake. However, there were obstacles for mothers to provide exclusive breastfeeding. Some mothers constrained by work or thought that giving formula milk could provide adequate nutrition for the baby (Alianmoghaddam et al., 2018). Providing adequate breastfeeding could increase the recovery duration for infants who were in low immunity (Little et al., 2019).

\section{The effect of family income on infants mortality}

The results of this study indicated that family income had an indirect effect on infant mortality. The result was statistically significant $(b=1.25 ; 95 \% \mathrm{CI}=0.59$ to 1.92 ; $\mathrm{p}<0.001)$. The infants whose families had high income could receive good health care and nutrition assurance compared to the infants whose families had low income. The infants whose families were low-income had 1.25 units higher logodd of experiencing death.

This is in line with a study conducted by Garcia et al., (2019) on income that family income statistically did not affect infant mortality but rather on biological factors such as low birth weight, disease burden, and preterm birth. According to a study conducted by Kumar et al., (2020), there were more babies born to families with low/poor economic status than babies with high economic status.

Based on a study conducted in India, $62 \%$ of infant mortality cases was caused by inequality of family wealth which caused malnutrition in children. This phenomenon occurred in all regions. However, in certain conditions in rural families, they had natural resources available to meet the nutritional needs of babies such as springs and vegetables. Families with low economic levels tend to have poor hygiene habits thus 
increasing the incidence of illness in infants (Singh et al., 2019).

\section{The effect of maternal education on infants mortality}

The result of this study indicated that there was an indirect effect between maternal education and infant mortality. The result was statistically significant $(b=-1.40 ; 95 \%$ $\mathrm{CI}=-2.19$ to $-0.62 ; \mathrm{p}<0.001)$. The infants whose mothers were above high school education received better health care. The infants whose mothers were above high school education had 1.40 units lower logodd of experiencing death than the infants whose mothers were above high school education.

Maternal education played a major role in infant mortality. Maternal education affected maternal knowledge, especially about the health of mothers and infants. The lack of knowledge reduced the use of health services. As a result, it inhibited both preventive and curative steps in infant health. In addition, the health care for infants decreased. High-educated mothers were more likely to have their pregnancies checked, thus preventing low birth weight and the nutrition of the babies was relatively fulfilled (Shrestha, 2020).

This is supported by Tambunan et al. (2020) that infants with low birth weight needed more health care than infants with normal birth weight. Poor knowledge of mothers and fathers caused low treatment strategies that were suitable for the baby's condition. Health care for babies was not in line with the needs that should be obtained by the infants with certain health problems.

\section{The effect of nutritional intake of infants on infants mortality}

The result of this study indicated that the nutritional intake of infants had a direct effect on infant mortality. The result was statistically significant $(b=4.07 ; 95 \% \mathrm{CI}=$ 2.25 to $5.89 ; \mathrm{p}<0.001)$. The infants who received good nutrition would have good endurance. The infants who received poor nutrition had 1.40 units lower loggodd of experiencing infant mortality than the infants who received good nutrition.

According to a study by Pai et al., (2018), the fulfillment of infant nutrition with breast milk obtained from the mother affected the baby's immunity. The infants who were born had environmental adjustments. The breastfeeding could form and activate the baby's immunity in the external environment. Malnutrition in infants caused susceptibility to infection. The infants who were infected were 5 times more likely to die than the infants who were not infected (Sania et al., 2018).

This study was in line with another study that infants who were adequately breastfed rarely had illnesses such as diarrhea, anemia, or respiratory disease ( $p<0.001)$. The fulfillment of good nutrition could speed up the healing process. Sufficient nutrition for babies by providing formula milk, cereal, and instant baby porridge could only meet $50 \%$ of the micronutrients needed by the infants (GómezMartín et al., 2019).

\section{The effect of immunization status on infants mortality}

The result of this study indicated that immunization status had an indirect effect on infant mortality. The result was statistically significant $(b=-1.77 ; 95 \% \mathrm{CI}=-2.46$ to -1.07; $\mathrm{p}<0.001)$. The infants with complete immunization status had more self-protection. The infants whose immunization status was complete had 1.77 units lower loggodd than the infants whose immunization status was incomplete.

This is in line with a study by Duszynski et al., (2019) that there was a difference in infant mortality between infants who were obedient to do immunization up to the age of 4-6 months, decreasing from 127.4 to 
59.3 per 100,000 infants at that age. Infant mortality were caused by infectious diseases. It could be prevented through immunization, such as respiratory infections that were very common in infants (Baral et al., 2020).

This is in line with another study about the evaluation of infant mortality in Brazil by Camargos et al., (2020). After implementing the massive infant immunization program, the incidence of infant mortality caused by meningitis, pneumonia, and diarrhea decreased significantly $(\mathrm{p}<0.005)$ each year. Infant mortality from viral infection was exacerbated by a poor innate antibody system (Lindholm et al., 2020).

\section{The effect of illness history of infants on infants mortality}

The results of this study indicated that the illness history of the infants had a direct effect on infant mortality. This was statistically significant $(b=3.03 ; 95 \% \mathrm{CI}=1.34$ to 4.72; $\mathrm{p}<0.001)$. The infants with a good medical history were less likely to get sick. The infants who were frequently sick had a 3.03 unit higher loggodd of having death.

This is in line with a study conducted by McAllister et al., (2019) which observed that all sick infants in the world were caused by pneumonia, pneumonia due to HIV and other causes, $49 \%$ of deaths occurred in infants with pneumonia. All of these infants had a history of poor health. They were aggravated by other infant conditions such as LBW, dyspnea, malnutrition, non-exclusive breastfeeding, indoor air pollution, incomplete immunization, and pediatric HIV.

There was a decrease in infant morbidity in the last five years due to pneumonia, diphtheria, high fever, and a significant reduction in mortality $(\mathrm{p}<0.005)$ from 8.3 to 3.6 per 1000 live birth rates (Onambele et al., 2019). Based on the illness history of infants, it often occurred in infants born prematurely or infants who had LBW (Yamakawa et al., 2016).

\section{The effect of birth weight on infants mortality}

The result of this study indicated that LBW had an indirect effect on infant mortality. The result was statistically significant $(b=-1.09$; 95\%CI $=-1.82$ to $-0.36 ; \mathrm{p}=0.003$ ). The infants whose birth weight was normal had a 1.09 units lower loggodd of having death than the infants whose birth weight was abnormal.

This is in line with a study that caused infants with LBW to be more susceptible to experience illnesses such as heart problems, respiratory problems, chronic lung disease which had the potential to die ( $\mathrm{Su}$ et al., 2016). The infants with LBW had a 1.3 times lower quality of life and ability to adapt until the age of 5 years than the infants with normal birth weight (Vidhale, 2020).

The infants with LBW were susceptible to death because they had birth defect by $6.2 \%$, such as heart defects, digestive system disorders, and labiopalatoskizis. Infant mortality with disabilities was more common and statistically significant $(\mathrm{p}<0.005)$ than infants without disabilities (Kawasaki et al., 2020).

\section{The effect of cleanliness of home environment on infants mortality}

The result of this study indicated that the cleanliness of the home environment had a direct effect on infant mortality. The result was statistically significant $(b=3.84 ; 95 \%$ $\mathrm{CI}=1.76$ to $5.92 ; \mathrm{p}<0.001)$. The infants who lived in clean environments tend to have a good level of health. The infants who lived in poor environments had 3.84 units higher loggodd of experiencing death than the infants who lived in clean environments.

Based on a study by Gouveia et al. (2018), a clean environment would improve the infants' health. Poor environment, especially air circulation in the house, caused 
respiratory tract disorders in infants. There was a significant result of infants who died from respiratory problems due to the effect of poor air sanitation. Infant mortality could be reduced by changing the environmental hygiene, especially the right waste management, the clean waters, and the awareness to maintain environmental hygiene periodically (Karimi and Shokrinezhad, 2020).

\section{The effect of the health care faci- lity on infants mortality}

The result of this study indicated that health care had an indirect effect on infant mortality. The result was statistically significant $(b=1.17 ; 95 \% \mathrm{CI}=0.49$ to $1.85 ; \mathrm{p}=$ o.001). The infants who received secondary health care were mostly in a more serious condition. The infants who received secondary health care had 1.17 units higher loggodd of experiencing death than the infants who received primary health care.

Basic health care should focus on promotive and preventive management. In caring for infants' health, ignoring promotive steps could affect the quality of children's health. In this study, almost $80 \%$ of healthy infants accessed primary health care both in the community health center or with an independent practice midwife, another 20\% usually visited a specialist in a clinic due to family beliefs (Njoh et al., 2019)

In the case of infant mortality, almost $75 \%$ of the infants visited the hospital when they had experienced ongoing illness, while $35 \%$ of the infants visited the community health center for economic reasons. The greater the coverage of primary health care, the more maternal and infant mortality could be prevented (Akinlo and Sulola, 2019).

\section{AUTHOR CONTRIBUTION}

Endang Palupi was the main researcher who collected the data, formulated the data, designed the study, and conducted the questionnaire reliability tests. Bhisma Murti checked the data and analyzed the data. Harsono Salimo gave the suggestion for the discussion of the study and writing techniques.

\section{CONFLICT OF INTEREST}

The authors declare that there is no conflict of interest in the publication of this article.

FUNDING AND SPONSORSHIP

This study used personal fund from the main researcher.

\section{ACKNOWLEDGEMENT}

We would like to thank the Karanganyar Health Office and all heads of the Community health centers in Karanganyar Regency, the cadres of the Integrated health post who helped carry out this study. We would like to thank the respondents represented by the mothers of the babies who gave their time to become the study subjects

\section{REFERENCE}

Akinlo AE, Sulola AO (2019). Health care expenditure and infant mortality in sub-Saharan Africa. J Policy Model, 41(1): 168-178. https://doi.org/10.10 16/j.jpolmod.2018.09.001

Baral R, Li X, Willem L, Antillon M, Vilajeliu A, Jit M, Beutels P, Pecenka C (2020). The impact of maternal RSV vaccine to protect infants in Gavisupported countries: Estimates from two models. Vaccine, 38(33): 51395147. https://doi.org/10.1016/j.vaccine.2020.06.036

Camargos P, Nascimento-Carvalho CM, Teixeira R, França E (2020). Lower respiratory infections mortality among Brazilians under-five before and after national pneumococcal conjugate vaccine implementation. Vaccine, 38(11): 2559-2565. https://doi.- 
Palupi et al./ Healthy Behavior and other Determinants on Infant Mortality

org/10.1016/j.vaccine.2020.01.084.

Dalili H, Shariat M, Nayeri F, Emami Z, Sahebi R, Sahebi L (2019). Exclusive Breastfeeding Duration and its Effect on the Health of the Children in Iran, a Meta Analysis. J Pediatr Nurs, 48: e8-e14. https://doi.org/10.1016/j.pedn.20 19.04.030.

Dinas Kesehatan Kabupaten Karanganyar (2020). Profil Kesehatan Kabupaten Karanganyar. Retrieved from profilkesehatan-kab.-karanganyar-2018.pdf Duszynski KM, Pratt NL, Lynch JW, Berry JG, Gold, MS (2019). Use of different combination diphtheria-tetanus-a cellular pertussis vaccines does not increase risk of 30-day infant mortality. A population-based linkage cohort study using administrative data from the Australian Childhood Immunisation Register and the $\mathrm{N}$. Vaccine, 37(2): 280-288. https://doi.org/10.1016/j.vaccine.2018.11.025.

Garcia LP, Fernandes CM, Traebert J (2019). Risk factors for neonatal death in the capital city with the lowest infant mortality rate in Brazil. J Pediat Brazil, 95(2): 194-200. https://doi.org/10.1016/j.jped.2017.12.007

Gómez-Martín M, Arboleya S, Gueimonde M, González S (2019). Nutritional composition of processed baby foods targeted at infants from $0-12$ months. J Food Compost Anal, 79(2018):5562. https://doi.org/10.1016/j.jfca.2019.03.009.

Gouveia N, Junger WL, Romieu I, Cifuentes LA, de Leon AP, Vera J, Strappa V, Hurtado-Díaz M, Miranda-Soberanis V, Rojas-Bracho L, Carbajal-Arroyo L, Tzintzun-Cervantes G (2018). Effects of air pollution on infant and children respiratory mortality in four large Latin-American cities. Environ Pollut,
232: 385-391. https://doi.org/10.10 16/j.envpol.2017.08.125

Karimi B, Shokrinezhad B (2020). Air pollution and mortality among infant and children under five years: A systematic review and meta-analysis. Atmos Pollut Res, 11(6): 61-70. https://doi.org/10.1016/j.apr.2020.0 2.006.

Kawasaki H, Yamada T, Takahashi Y, Nakayama $\mathrm{T}$, Wada $\mathrm{T}$, Kosugi $\mathrm{S}$ (2020). Epidemiology of Birth Defects in Very Low Birth Weight Infants in Japan. J Pediatr. https://doi.org/10.1016/j.jpe ds.2020.07.012.

Kawuki J, Musa TH, Ongecu P (2020). Dietary practices, WASH conditions, and disease occurrence among children below five years in households of Nangabo, Wakiso district, Uganda. Scientific African, 7, eoo291. https://doi.org/10.1016/j.sciaf.2020.e00291

Kemenkes RI (2017). Survey Demografi dan Kesehatan Indonesia. https://doi.org/ 0910383107[pii] \r10.1073/pnas.0910 383107

Kementerian Perencanaan Pembangunan Nasional Republik (2015). Laporan Perkembangan Pencapaian Tujuan Pembangunan Milenium Indonesia, 51-56. Retrieved from https://www. bappenas.go.id/files/2113/6082/989

3/indonesiamdgbigoal4__200811220 01221_518.pdf

Kumar P, Patel, R., Chauhan, S., Srivastava, S, Khare A, Kumar Patel K (2020). Does socio-economic inequality in infant mortality still exists in India? An analysis based on National Family Health Survey 2005-06 and 2015-16. Clin Epidemiol Glob Health. https:// doi.org/10.1016/j.cegh.2020.07.010

Lamichhane R, Zhao Y, Paudel S, Adewuyi EO (2017). Factors associated with infant mortality in Nepal: A compa- 
Palupi et al./ Healthy Behavior and other Determinants on Infant Mortality

rative analysis of Nepal demographic and health surveys (NDHS) 2006 and 2011. BMC Public Health, 17(1): 1-18. https://doi.org/ 10.1186/s12889-0163922-z.

Lindholm DE, Licciardi PV, Ratu FT, Kim Mulholland E, Nguyen CD, Russell FM (2020). Predictors of antibody persistence to the 7-valent pneumococcal conjugate vaccine in healthy Fijian infants at 12 months of age. Vaccine, 38(33): 5095-5099. https://doi.org/10.1016/j.vaccine.2020.06. 025 .

Little EE, Polanco MA, Baldizon SR, Wagner P, Shakya H (2019). Breastfeeding knowledge and health behavior among Mayan women in rural Guatemala. Soc Sci Med, 242(August): 112565. https://doi.org/10.1016/j.socscimed.2019.112565.

McAllister DA, Liu L, Shi T, Chu Y, Reed C, Burrows J, Adeloye D, Rudan I, Black RE, Campbell H, Nair H (2019). Global, regional, and national estimates of pneumonia morbidity and mortality in children younger than 5 years between 2000 and 2015: a systematic analysis. Lancet Glob Health, 7(1): e47-e57. https://doi.org/10.1016/S2214109X(18)30408-X.

Njoh AJ, Ricker F, Joseph N, Tarke MO, Koh B (2019). The impact of basic utility services on infant mortality in Africa. Util Policy, 59(May): 100928. https://doi.org/10.1016/j.jup.2019.10 0928.

Onambele L, San-Martin-Rodríguez L, Niu $\mathrm{H}$, Alvarez-Alvarez I, Arnedo-Pena A, Guillen-Grima F, Aguinaga-Ontoso I (2019). Infant mortality in the European Union: A time trend analysis of the 1994-2015 period. An pediatr (Barc), 91(4): 219-227. https://doi. org/10.1016/j.anpede.2019.03.002.
Pai UA, Chandrasekhar P, Carvalho RS, Kumar S (2018). The role of nutrition in immunity in infants and toddlers: An expert panel opinion. Clin Epidemiol Glob Health, 6(4): 155-159. https://doi.org/10.1016/j.cegh.2017.1 1.004 .

Sania A, Smith ER, Manji K, Duggan C, Masanja H, Kisenge R, Msamanga G, Urassa W, Fawzi W (2018). Neonatal and Infant mortality risk associated with preterm and small for gestational age births in Tanzania: Individual Level pooled analysis using the intergrowth standard. J Pediatr, 192: 6672.e4. https://doi.org/10.1016/j.jpeds.2017.09.007.

Shrestha V (2020). Maternal education and infant health gradient: New answers to old questions. Econ Hum Biol, 39: 100894. https://doi.org/10.1016/j.ehb.2020.100894.

Singh S, Srivastava S, Upadhyay AK (2019). Socio-economic inequality in malnutrition among children in India: An analysis of 640 districts from National Family Health Survey (2015-16). Int J Equity Health, 18(1): 1-9. https://doi.org/10.1186/s12939-019-1093-0

Su YY, Wang SH, Chou HC, Chen CY, Hsieh WS, Tsao PN, Tsou KI, Hsu C H, Mu $\mathrm{SC}$, Lin HC, Huang CC, Hsieh KS (2016). Morbidity and mortality of very low birth weight infants in Taiwan-Changes in 15 years: A population based study. J Formos Med Assoc, 115(12): 1039-1045. https://doi.org/10.1016/j.jfma.2016.10.011.

Tambunan ES, Pratomo H, Hadi EN, Rustina Y (2020). Knowledge of low birth weight care as a source of coping strategies for mothers: Cross sectional study in perinatology WARD'S. J Perinat Neonat Nur, 5(2019): 0-1. https://doi.org/10.1016/j.jnn.2020.01.003. 
Palupi et al./ Healthy Behavior and other Determinants on Infant Mortality

Teijeiro A, Cuello MN, Raiden MG, Vieyra RE, Solé D, Ellwood P, Gomez RM (2020). The relationship between second-hand smoke and wheezing in infants from Córdoba, Argentina. Allergologia et Immunopathologia, 48(1): 42-47. https://doi.org/10.10 16/j.aller.2019.06.010

UN IGME (2015). Millenium Development Goals and Beyond. Retrieved from https://un.org/millenniumgoals/chil dernhealth.shtml.

Vidhale P, Puri S, Bhongade ML (2020). A relationship between maternal periodontal disease and preterm low birth weight: A cross-sectional study. Clin Epidemiol Glob Health. https://doi:10.1016/j.cegh.2020.04.007.

Vijay J, Patel KK (2020). Risk factors of infant mortality in Bangladesh. Clinical Epidemiology and Global Health,
8(1): 211-214. https://doi.org/10.1016/j.cegh.2019.07.003.

Ware JL, Mzayek F, Levy M (2016). Lessons learned in a breastfeeding media campaign. Breastfeed Med, 11(7): 380385. https://doi.org/10.1089/bfm.20 16.0047.

WHO (2017). Nurturing the health and wealth of nations: the investment case for breastfeeding. Retrieved from http://www.who.int/nutrition/public ations/infantfeeding/global-bf-collective-investmentcase.pdf?ua $=1$

Yamakawa T, Itabashi K, Kusuda S (2016). Mortality and morbidity risks vary with birth weight standard deviation score in growth restricted extremely preterm infants. Early Hum Dev, 92: 7-11. https://doi.org/10.1016/j.earlhumdev.2015.10.019. 